\title{
The effects of defaunation of the rumen on the growth of lambs on low-protein-high-energy diets
}

\author{
BY S. H. BIRD, M. K. HILL* AND R. A. LENG \\ Departments of Biochemistry and Nutrition and *Animal Science, University of New England, \\ Armidale, NSW 235I, Australia
}

(Received I9 September 1978 - Accepted 20 October 1978)

\begin{abstract}
I. The effects of defaunation of the rumen of lambs given low-protein-high-energy diets were studied using animals fed ad lib. a basal diet of sugar and oaten chaff which was supplemented with fish meal at various levels. These diets supported relatively large populations of protozoa in the rumen.

2. A nonyl phenol ethoxylate (I 5 g, Teric GN9; ICI Australia Ltd) given intraruminally, was shown to be an effective means of defaunating the rumen and the lambs were maintained protozoa-free by isolation.

3. In lambs given low levels of fish meal in the diet, the absence of rumen protozoa increased growth rate and improved the food conversion efficiency ( $g$ dry matter intake/g growth). These effects were not apparent at high levels of protein supplementation.

4. These results suggested that the absence of rumen protozoa resulted in an increased availability of nutrients supplying both energy and amino acids since the efficiency of food utilization and the rate of wool growth (which is sensitive to amino acid supply) were increased in lambs on the low level of protein supplementation without apparently increasing food intake.
\end{abstract}

The role of protozoa in the rumen in relation to animal production has become of considerable interest recently with the suggestion that protozoa are retained in the rumen of sheep on roughage diets (see Weller \& Pilgrim, 1974) or cattle on sugar-cane diets (Minor et al. 1977) and cattle and sheep grazing rapidly-growing rye grass-clover pastures (see Bird et al. I 978). The low numbers of protozoa which apparently leave the rumen have caused Leng (1976) and Bergen \& Yokoyama (1977) to speculate that the amount of microbial protein available to the host animal may be decreased by the presence of significant populations of protozoa. This may limit the productivity of ruminants, particularly when protein content of the food is low.

Studies with cattle have confirmed that defaunation increases production on low-proteinmolasses-based diets (Bird \& Leng, 1978). However, the response to defaunation demonstrated in that study could not be explained completely by an increased protein outflow from the rumen since the animals' food intake did not increase when protozoa were removed but food conversion efficiencies were improved. This suggested that in addition to a possible increased protein supply, the availability of nutrients which largely supply energy may have also increased in the defaunated state.

In order to study further the effects of the defaunated state on production in ruminants on high-energy-low-protein diets, young growing lambs were given a basal diet of sugar and oaten chaff which was supplemented with various levels of protein and half the animals on each diet were defaunated. Although food intake was unaffected, growth rate was improved at low protein intakes and wool growth rate was increased at all levels of supplementation in the defaunated as compared to the faunated lambs. The results suggest that there may have been an increased availability of nutrients that supplied both energy and amino acids in lambs without protozoa present in their rumens. 
Table I. Composition $(\mathrm{g} / \mathrm{kg})$ of diets

\begin{tabular}{|c|c|c|c|c|}
\hline \multirow[b]{2}{*}{ Ingredient } & \multicolumn{4}{|c|}{ Diet } \\
\hline & A & B & C & $\mathrm{D}$ \\
\hline Oaten chaff & 472 & 454 & 439 & 424 \\
\hline Sugar* & 472 & 454 & 439 & 424 \\
\hline Urea & 38 & 36 & 35 & 34 \\
\hline $\mathrm{NaCl}$ & $4 \cdot 7$ & 4.5 & $4 \cdot 4$ & $4 * 2$ \\
\hline $\mathrm{Na}_{2} \mathrm{SO}_{4}$ & $4 \cdot 7$ & 4.5 & $4 \cdot 4$ & $4 \cdot 2$ \\
\hline Mineral Mix $\dagger$ & $4 \cdot 7$ & $4 \cdot 5$ & $4 \cdot 4$ & $4 \cdot 2$ \\
\hline $\mathrm{Ca}_{2} \mathrm{P}_{2} \mathrm{O}_{7}$ & $4 \cdot 7$ & 4.5 & $4 \cdot 4$ & $4 \cdot 2$ \\
\hline Fish meal & - & 36 & 70 & 102 \\
\hline $\begin{array}{l}\text { Crude protein }(\mathrm{N} \times 6.25) \ddagger \\
\text { (g/kg diet) }\end{array}$ & 28 & 46 & 63 & 79 \\
\hline
\end{tabular}

\section{MATERIALS AND METHODS}

\section{Experimental animals}

Mixed sex Corriedale lambs approximately 6 months of age and weighing an average $20 \mathrm{~kg}$ live weight were obtained from a flock of sheep at pasture. All animals had been weaned approximately 2 months before selection and before being placed indoors in individual pens the lambs were treated for the elimination of internal parasites by the following drenches at $4 \mathrm{~d}$ intervals: $7.7 \mathrm{ml}$ Ranizole (Merck Sharp \& Dohme Australia Pty Ltd), $7.5 \mathrm{ml}$ Ranide (Merck Sharp \& Dohme Australia Pty Ltd) and $8 \mathrm{ml}$ Nilverm (ICI Australia Ltd), a drenching procedure which successfully produced lambs free of intestinal parasites.

Forty-eight lambs were allocated on a weight basis to eight treatments using a randomized block design. Faunated and defaunated animals were separated on either side of an animal house $5 \mathrm{~m}$ apart. Within these treatment groups the animals were given four dietary regimes. Water was continuously available.

\section{Diets}

All animals were fed ad lib. a basal diet of oaten chaff and sugar (I:I, w/w). For every I kg sugar (grade A table sugar; CSR Australia Ltd), $80 \mathrm{~g}$ urea was added together with (g): Io sodium sulphate, Io calcium pyro phosphate, ro sodium chloride, 10 mineral-trace element mix (Minavit; Cooper Australia Pty Ltd). The basal diet was supplemented with four levels of fish meal ( $520 \mathrm{~g}$ crude protein (nitrogen $\times 6 \cdot 25) / \mathrm{kg}$ ) at $0,80, \mathrm{I} 60$ and $240 \mathrm{~g} / \mathrm{kg}$ sugar in the diet, providing four dietary regimes A, B, C and D respectively (see Table $\mathrm{I}$ ). All animals were fed at $09.00 \mathrm{~h}$ each day.

Animals were allowed a 3-week period to adjust to their new dietary regimen before commencement of the experiment.

\section{Experimental procedures}

Defaunation was achieved by inserting a soft polyethylene tube (I $2 \mathrm{~mm}$ internal diameter) into the rumen and delivering $15 \mathrm{~g}$ nonyl phenol ethoxylate (Teric GN9; ICI Australia Ltd) in $120 \mathrm{ml}$ water. Rumen fluid samples were obtained (using a stomach tube) at weekly intervals from treated lambs in order to monitor protozoal numbers. Six of the twenty-four Teric-treated animals were found to contain protozoa within the rumen (small Entodiniomorphs $1 \times 10^{3} / \mathrm{ml}$ ) after the third and fourth weeks and these animals were again treated with $15 \mathrm{~g}$ Teric. After this treatment all animals remained free of protozoa for the rest of 
Table 2. The effects of defaunation on food intake, growth and food conversion efficiency of lambs fed ad lib. a basal diet of sugar and oaten chaff $(\mathrm{I}: \mathrm{I} w / w)$ and supplemented with four levels of fish meal $(0,80,160,240 \mathrm{~g} / \mathrm{kg}$ sugar in the diet (diet $A, B, C, D$ respectively))

(Mean values with their standard errors for six animals)

\begin{tabular}{|c|c|c|c|c|c|c|}
\hline Diet & Group & $\begin{array}{c}\text { Initial } \\
\text { live-wt } \\
\text { (kg) }\end{array}$ & $\begin{array}{l}\text { No. of } \\
\text { protozoa } \\
\text { in rumen } \\
\text { fluid } \\
\left(\times 10^{-5} / \mathrm{ml}\right)\end{array}$ & $\begin{array}{l}\text { Mean dry } \\
\text { matter } \\
\text { intake } \\
(\mathrm{DMI}) \\
\text { (g/d) }\end{array}$ & $\begin{array}{l}\text { Mean } \\
\text { growth } \\
\text { rate } \\
(\mathrm{g} / \mathrm{d})\end{array}$ & $\begin{array}{l}\text { Food con- } \\
\text { version } \\
\text { efficiency } \\
\text { (g DMI/g } \\
\text { growth) }\end{array}$ \\
\hline A & $\begin{array}{l}\text { Faunated } \\
\text { Defaunated }\end{array}$ & $\begin{array}{l}22 \cdot I \\
2 I \cdot 7\end{array}$ & $\begin{array}{l}8 \cdot 0 \\
-\end{array}$ & $\begin{array}{l}387^{\mathrm{a}} \\
454^{\mathrm{a}}\end{array}$ & $\begin{array}{r}-11 \cdot 5^{a} \\
37^{b}\end{array}$ & $\overrightarrow{37 \cdot 3}$ \\
\hline B & $\begin{array}{l}\text { Faunated } \\
\text { Defaunated }\end{array}$ & $\begin{array}{l}22 \cdot 4 \\
21 \cdot 2\end{array}$ & $\begin{array}{l}6 \cdot 4 \\
-\end{array}$ & $\begin{array}{l}645^{\mathrm{b}} \\
693^{\mathrm{b}}\end{array}$ & $\begin{array}{r}75^{\mathrm{c}} \\
133^{\mathrm{d}}\end{array}$ & $\begin{array}{l}8 \cdot 5 \\
5 \cdot 3\end{array}$ \\
\hline C & $\begin{array}{l}\text { Faunated } \\
\text { Defaunated }\end{array}$ & $\begin{array}{l}21 \cdot 8 \\
21 \cdot 8\end{array}$ & 4.9 & $\begin{array}{l}660^{b} \\
685^{b}\end{array}$ & $\begin{array}{l}146^{\mathrm{d}} \\
159^{\mathrm{de}}\end{array}$ & $\begin{array}{l}4 \cdot 7 \\
4 \cdot 4\end{array}$ \\
\hline D & $\begin{array}{l}\text { Faunated } \\
\text { Defaunated }\end{array}$ & $\begin{array}{l}22 \cdot 5 \\
22 \cdot 5\end{array}$ & 5.8 & $\begin{array}{l}745^{b} \\
735^{b}\end{array}$ & $\begin{array}{l}\mathrm{I} 79^{\mathrm{e}} \\
\mathrm{I} 54^{\mathrm{d}, \mathrm{e}}\end{array}$ & $\begin{array}{l}4 \cdot 2 \\
4 \cdot 9\end{array}$ \\
\hline & SEM & \pm 0.3 & & $\pm 4 \mathrm{I} \cdot 5$ & $\pm I I \cdot I$ & \\
\hline
\end{tabular}

Values in one column with different superscripts are significantly different at $P<0.05$.

the trial. Rumen fluid samples were collected from untreated lambs at 2-week intervals during the experiment.

After defaunation of the treated groups, all animals were placed on their various dietary regimens and food intake was measured daily and live-weight change was monitored at weekly intervals during the course of the experiment which was of 6 weeks' duration.

Wool growth rate was measured using the mid-side patch method of Ferguson et al. (1949). At the beginning of the experiment a patch (area $100 \times 100 \mathrm{~mm}$ ) was clipped from the right mid-side of each lamb. The wool grown during the 6-week experimental period was clipped from within these mid-side patches at the end of the trial and the clean dry weight was determined by the method of Turner et al. (I953).

\section{RESULTS}

In general the untreated animals had protozoal populations in the rumen of the order of $5 \times 10^{5} / \mathrm{ml}$ and it was evident that the level of protein in the diet did not affect the composition or the number of protozoa in the rumen population (Table 2). Small Entodinia made up $96 \%$ of the total protozoal population.

\section{Food intake and live-weight gain}

Results obtained for dietary intake, initial live weight, live-weight gain and food conversion efficiency ( $\mathrm{g}$ dry matter intake/g growth) from lambs on each diet are summarized in Table 2.

There was a significant increase in growth as the level of fish meal in the diet was increased for both groups of animals, the defaunated animals tending to plateau in their response at the two highest levels of protein in the diet (Table 2).

There was a significant effect of the defaunated state $(P<0.05)$ on the growth rate of lambs on the two lowest levels of protein supplementation, but there was no significant effect $(P>0.05)$ on those given the higher levels of protein supplementation. 


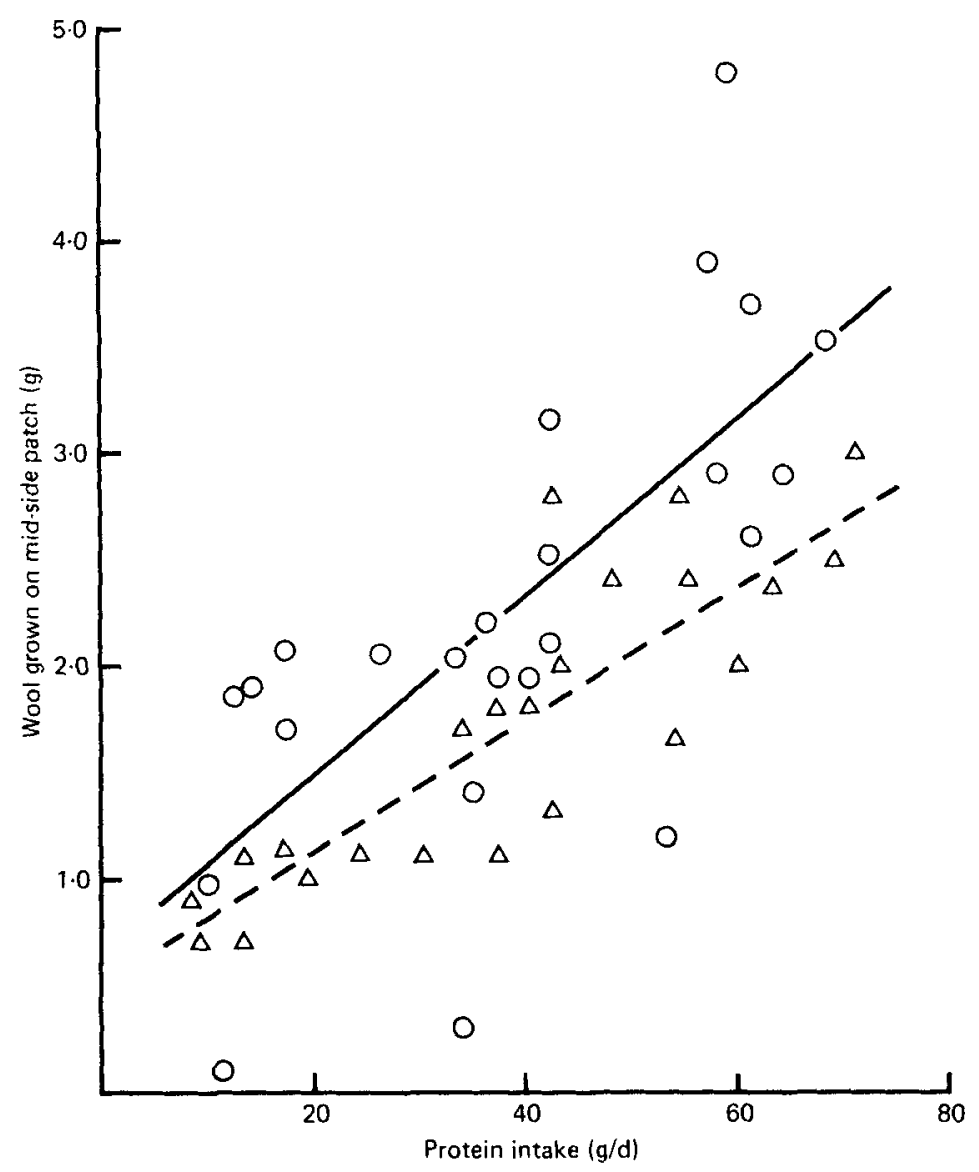

Fig. I. Relationship betweeen wool growth (clean weight (g) of wool grown on a $100 \times 100 \mathrm{~mm}$ mid-side patch in 6 weeks) and crude protein (nitrogen $\times 6.25$ ) intake (excluding the urea in the diet) $(\mathrm{g} / \mathrm{d}$ ) of lambs with $(\triangle)$ and without $(O)$ protozoa. The animals were fed ad lib. a basal diet of oaten chaff and sugar.

Food intake increased significantly in both the control and defaunated lambs as the protein level in the diet increased but there was no significant effect of the defaunated state on food intake at any of the levels of protein supplementation. The food conversion efficiencies of lambs on the two low-protein diets were thus improved significantly by removing protozoa from the rumen.

\section{Wool growth}

Wool growth was increased at all protein levels in the diet in the defaunated as compared to the control lambs. There was a linear relationship between wool growth and protein intake for the animals (with or without protozoa) as illustrated in Fig. I. The regressions were as follows:

$$
\begin{array}{ll}
Y_{1}=0.526+0.0313( \pm 0.0038) X_{1} & R^{2} 0.75 \\
Y_{2}=0.648+0.0419( \pm 0.0088) X_{2} & R^{2} 0.49,
\end{array}
$$

where $Y_{1}$ and $Y_{2}$ represent the total weights (g clean dry wool/6 weeks) of wool of the control and defaunated lambs respectively, and $X_{1}$ and $X_{2}$ the daily intake (g) of crude protein from fish meal and chaff. 
The slopes of these regressions did not differ but the intercepts were significantly different $(P<0.01)$.

\section{DISCUSSION}

Numerous studies have been carried out on the effects of either defaunation of the rumen of sheep, or the effects of maintaining sheep and cattle free of protozoa from birth, on growth rate (see Clarke, 1978, for recent review). In general the results have suggested that there is little or no effect of the defaunated state on animal production, though the diets which have been used in most studies have been based on concentrates (starch) and have usually also contained high concentrations of protein (in excess of $100-150 \mathrm{~g} / \mathrm{kg}$ ). The diet used in the study reported here was chosen specifically to provide a low-protein-high-energy intake which could be expected to support considerable numbers of protozoa within the rumen. This objective was achieved and the concentration of protozoa in the rumen of control lambs ranged from $0 \cdot 2-2 \times 10^{6} / \mathrm{ml}$, suggesting that the protozoal population represented approximately $50 \%$ of the total biomass of micro-organisms in the rumen (see Coleman, 1975; Leng, 1976). The protozoa present in the rumen of these animals consisted largely of Entodinia with the other predominant genus being Epidinium but Holotrich protozoa were absent.

The basal diet in the present study was chosen because recent experience had shown that this formulation would ensure production responses at low protein supplementation of the diet if any imposed treatment (in this instance the defaunated state) brought about a change in the quantity of digestible protein entering the intestines. Food intake and growth rate increased with increasing protein content of the diet.

The defaunating agent used in the present study was a nonyl phenol ethoxylate (Teric GN9) which was first shown to have antiprotozoal properties by Wright \& Curtis (1976). The I5 $\mathrm{g}$ Teric employed, initially removed protozoa from all animals and except for six animals (which had to be retreated) these remained free of protozoa for the whole of the experimental period of 6 weeks. The Teric treatment combined with the isolation of defaunated and control lambs was therefore extremely successful in maintaining protozoa-free animals in this experiment. Ambient temperature may also have contributed to this success since these studies were made in winter when air temperatures were usually less than $10^{\circ}$. In subsequent experiments carried out during the summer, when ambient temperatures were usually in excess of $25^{\circ}$, greater difficulties have been found in maintaining sheep and lambs in a protozoa-free state by the procedures used here.

Whilst the Teric has been shown to have antiprotozoal properties, the specific effects on the bacterial populations are at present unknown and therefore it is difficult to attribute the observed responses only to the absence of protozoa. However, without further information the results are discussed in relation to the defaunation treatment.

The results demonstrate that the absence of protozoa in lambs fed in a low-protein diet resulted in increased growth rate but had no effect on food intake. However, at high-protein intakes (which approach the levels that have been used in past studies on defaunation, see Eadie, I962; Eadie \& Gill, I97I ; Abou Akkada \& El Shazly, I964; Christiansen et al. 1965) the effects of the lack of protozoa were either not apparent or much reduced. The main effect of the absence of protozoa at low-protein intake was to increase the efficiency of utilization of food.

Wool growth was increased in defaunated as compared to untreated lambs on all four levels of protein supplementation, with significant differences in the regressions of wool grown (over the 6 week trial) against protein intake for animals with, or without, rumen protozoa. At the lower levels of protein intake, wool growth was increased by $50 \%$ as a result of defaunation, while at the higher levels of protein intake, it was increased by 
approximately $25 \%$. This means that the same level of live-weight gain and wool production could have been obtained with $30 \%$ less dietary 'bypass protein', i.e. undegraded in the rumen (fish meal) in the diet. Since wool growth is very sensitive to the amount of protein arriving at the duodenum this is suggestive of increased protein availability from the rumen in animals from which protozoa have been removed. However, as was the situation with studies on cattle (Bird \& Leng, I978), food intake was not increased by this apparent increase in protein availability at the duodenum. The increased efficiency of utilization of food which followed defaunation suggested that concomitant with an increase in protein availability, there was either an increased efficiency of utilization of available nutrients or an increased availability of non-protein energy nutrients. The latter possibility must be considered since the food intake was not higher in the defaunated animals, suggesting that the protein:energy in the absorbed nutrients may have remained constant following defaunation. At high-protein intakes live-weight change or food conversion ratios were similar in treated and non-treated groups, suggesting that either there was an increased efficiency of utilization of absorbed nutrients in the animal as the protein in the diet increased or there was some fundamental difference in rumen function in animals on the low-protein diets as compared to those on the high-protein intake.

These studies indicate that on high-energy-low-protein diets the presence of large populations of protozoa are apparently associated with an inefficiency of food utilization by lambs. Removal of protozoa obviously resulted in changes in the ecological system in the rumen which makes it difficult to define the mechanism responsible for the observed effects of the defaunated state.

It has been demonstrated by Eadie and Hobson (1962), Klopfenstein et al. (r966) and Eadie and Gill (197I) that when protozoa are removed from the rumen the bacterial population increases, filling the niche in the ecosystem. In recent studies with animals given molasses we have demonstrated the presence of large populations of a bacterium normally present in sewage and which oxidizes volatile fatty acids (Rowe et al. 1979) and we are currently examining whether these organisms are involved in the low efficiency of utilization of food in lambs on the low-protein diet.

At this time, the over-all effects observed in these studies cannot be definitely attributed to an effect of the defaunating agent or the absence of protozoa. However, since wool growth was increased in the absence of protozoa it appears reasonable to suggest that digestible protein available in the small intestines increased in the treated animals. This may result from a combination of factors including reduced predation of bacteria by protozoa (Coleman, 1975); increased bacterial cell availability and reduced recycling of microbial protein through a larger proportion of the microbial biomass leaving the rumen (Leng, 1976), or a combination of these. Lindsay and Hogan (1972) however found only an indication of increased microbial organic matter availability as a result of defaunation of sheep on high-protein diets. The apparent increased availability of protein may also result from a greater proportion of the digestible dietary protein leaving the rumen intact.

Experiments are under way to study in more detail the factors that are involved in the increased production at low protein intakes.

The authors wish to acknowledge the financial support of the Australian Meat Research Committee and the Australian Wool Research Committee for these studies and would also like to thank Messrs Bruce Cochran, Vince Scollen and Reginald Woodgate for technical assistance. 


\section{REFERENCES}

Abou Akkada, A. R. \& El Shazly, K. (1974). Appl. Microbiol. 12, 384.

Bergen, W. G. \& Yokoyama, M. T. (1977). J. Anim. Sci. 46, 573.

Bird, S. H., Baigent, D. R., Dixon, R. M. \& Leng, R. A. (1978). Proc. Aust. Soc, Anim. Prod. $12,137$.

Bird, S. H. \& Leng, R. A. (1978). Br. J. Nutr. 40, I63.

Christiansen, W. C., Kawashima, R. \& Burroughs, W. (1965). J. Anim. Sci. 24, 730.

Clarke, R. T. J. (1978). In Microbial Ecology of the Gut, p. 25 I [T. R. J. Clarke \& T. Bachop, editors]. London: Academic Press.

Coleman, G. S. (1975). In Digestion and Metabolism in the Ruminant, p. I49 [I. W. McDonald \& A. C. I. Warner, editors]. Armidale: University of New England Publishing Unit.

Eadie, J. M. (1962). J. gen. Microbiol. 29, 563.

Eadie, J. M. \& Gill, J. C. (1971). Br. J. Nutr. 26, 155.

Eadie, J. M. \& Hobson, P. N. (1962). Nature, Lond. 193, 503.

Ferguson, K. A., Carter, H. B. \& Hardy, M. H. (1949). Aust. J. biol. Sci. $2,42$.

Klopfenstein, T. J., Purser, D. B. \& Tyznik, W. J. (Ig66). J. Anim. Sci. 25, 765.

Leng, R. A. (1976). In Reviews in Rural Science Vol. 2 : From Plant to Animal Protein, p. 85 [T. M. Sutherland, J. R. McWilliam \& R. A. Leng, editors]. Armidale: University of New England Publishing Unit.

Lindsay, J. R. \& Hogan, J. P. (1972). Aust. J. agric. Res. 23, 321.

Minor, S., Macleod, N. A., Preston, T. R. \& Leng, R. A. (1977). Trop. Anim. Prod. 2, 163.

Rowe, J., Loughnan, M., Nolan, J. V. \& Leng, R. A. (I979). Br. J. Nutr. 41, 393.

Turner, H. H., Riches, J. H., Roberts, N. F. \& Wilson, L. T. (1953). Divl. Rep. Div. Anim. Hlth Prod. CSIRO, Aust 4, Ser.S.W.-2.

Weller, R. A. \& Pilgrim, A. F. (1974). Br. J. Nutr. 32, 34 I.

Wright, D. E. \& Curtis, M. W. (1976). N.Z. Jl agric. Res. 19, 23. 